\title{
OXIDATIVE STRESS PROFILE AND TYPE 2 DIABETES REMISSION AT 6 MONTHS AFTER SLEEVE GASTRECTOMY VERSUS CONSERVATORY TREATMENT
}

\author{
LIVIU IOSIF $^{1,2}$, DANIELA LIXANDRU ${ }^{1} *$, LAURA GAMAN ${ }^{1}$, MIHAELA ILIE ${ }^{1}$, BOGDAN SMEU $^{3}$, \\ DIANA SIMONA ŞTEFAN ${ }^{1,4}$, LAURA PETCU ${ }^{4}$, ARIANA PICU ${ }^{4}$, ALINA CONSTANTIN $^{5}$, \\ CONSTANTIN IONESCU-TÎRGOVIŞTE ${ }^{1,4}$, CRISTIAN GUJA ${ }^{1,4}$, CĂTĂLIN COPĂESCU ${ }^{3}$, IRINA \\ STOIAN $^{1,2}$
}

I "Carol Davila” University of Medicine and Pharmacy, Bucharest, Romania

${ }^{2} R \& D$ Irist Labmed SRL, Bucharest, Romania

${ }^{3}$ Ponderas Academic Hospital, Bucharest, Romania

4 "Prof. N.C. Paulescu" National Institute of Diabetes, Nutrition and Metabolic Diseases, Bucharest, Romania

5 "Nicolae Simionescu”" Institute of Cellular Biology and Pathology, Bucharest, Romania

*corresponding author: daniela.lixandru@umfcd.ro

\begin{abstract}
The aim of this study was to examine the impact of weight loss on oxidant-antioxidant profile in obese T2D patients. The study was carried out on 38 obese T2D males randomized in two groups, one that underwent laparoscopic sleeve gastrectomy (LSG) and the other an intensive diet intervention (DTG) and standard diabetes treatment. Body mass index (BMI), fasting blood glucose, total cholesterol, HDL-cholesterol, triglycerides, $\mathrm{HbA}_{1 \mathrm{c}}$ and $\mathrm{C}$ Reactive Protein (CRP) were evaluated at baseline and after 6 months of follow-up. Ghrelin, insulin, C peptide, leptin and adiponectin were also measured in all subjects by ELISA method. For oxidative stress profile, "Respiratory Burst" and the antioxidants enzymes: paraoxonase1 (PON1), glutationperoxidase (GPx) and catalase (CAT) were evaluated. After LSG, BMI and metabolic control improved significantly: weight loss $78.98 \%$, fasting plasma glucose (FPG) $<11.0 \mathrm{mmol} / \mathrm{L}$ and $\mathrm{HbA}_{1 \mathrm{c}}<6 \%$. Antioxidant enzymes GPx and CAT increased after 6 months in both groups. By using univariate conditional regression model we were able to highlight that patients with an unfavourable evolution regarding T2D remission $\left(\mathrm{HbA}_{1 \mathrm{c}}>6 \%\right.$ ) had higher values (at baseline and after 6-months) for BMI, C peptide and CRP and lower values (at baseline and after 6 months) for HDL and adiponectin (as an anti-inflammatory factor). We conclude that the significant weight fluctuations can directly influence antioxidant enzyme profiles and may play an important role in the mediation of weight loss and the beneficial metabolic effects of LSG.
\end{abstract}

\section{Rezumat}

Scopul acestui studiu a fost de a examina impactul pierderii în greutate asupra profilului oxidant-antioxidant la pacienți obezi cu DZ2. Studiul a inclus 38 bărbați cu DZ2 şi obezitate randomizați în două loturi supuse fie gastrectomiei longitudinale (LSG), fie unui tratament conservator: intervenție dietetică intensivă (DTG) asociat cu tratament standard al DZ2. Glicemia a jeun, colesterolul total, HDL-colesterolul, trigliceridele, $\mathrm{HbA}_{1 c}$, proteina $\mathrm{C}$ reactivă $(\mathrm{PCR})$ şi indicele de masă corporală (IMC) au fost evaluate la momentul inițial și după 6 luni de urmărire. Ghrelina, insulina, proinsulina, peptidul C, leptina și adiponectina au fost de asemenea măsurate la toți subiecții prin metoda ELISA. Pentru statusul oxidant, "Respiratory Burst" și enzimele antioxidante paraoxonaza1 (PON1), glutationperoxidaza (GPx) și catalaza (CAT) au fost de asemenea evaluate. După LSG, greutatea şi controlul metabolic s-au îmbunătățit semnificativ, după cum urmează: pierderea în greutate 78,98\%, glicemia $<110$ $\mathrm{mmol} / \mathrm{L}$ şi $\mathrm{HbA}_{1 \mathrm{c}}<6 \%$. Enzimele GPx şi CAT au crescut semnificativ statistic la 6 luni în ambele grupuri. Prin utilizarea unui model de regresie condiționată univariată am reușit să subliniem faptul că pacienții cu evoluție nefavorabilă pentru remisia DZ2 $\left(\mathrm{HbA}_{1 \mathrm{c}}>6 \%\right)$ au avut valori mai mari (la momentul inițial și după 6 luni) pentru IMC, peptidul C şi PCR și valori mai scăzute valoarea inițială și după 6 luni) pentru HDL și adiponectina (ca factori antiinflamatori). Rezultatele noastre sugerează că fluctuațiile greutății urmate de modificarea profilului antioxidant ar putea juca un rol important în efectul metabolic benefic al LSG pentru remisia DZ2.

Keywords: laparoscopic sleeve gastrectomy, oxidative stress, antioxidant enzymes

\section{Introduction}

Oxidative stress is strongly associated with obesity, vascular function, and type 2 diabetes (T2D). Both dietary intervention [1] and laparoscopic sleeve gastrectomy (LSG) [2] have been shown to be successful weight loss interventions that may also improve markers of oxidative stress. The fact that surgical procedures improve the metabolic profile in type 2 diabetes, often in a weight-loss independent manner has led to the development of the concept of metabolic surgery [2]. Nowadays, laparoscopic 
FARMACIA, 2019, Vol. 67, 1

adjustable gastric banding (LABG), laparoscopic sleeve gastrectomy (LSG), and malabsortive procedures (biliopancreatic diversion (BPD), duodenal switch (DS)), or a combination of both (Roux-en-Y gastric bypass (RYGB)) are well known techniques for weight loss. All these are generally known as bariatric (metabolic) surgery techniques. A number of studies have shown that changes in gut hormone concentrations may partially explain weight loss following bariatric surgery [3, 4]. Furthermore, metabolic surgery induces a significant improvement in glycaemic control (up to diabetes remission). Recent studies show an accelerated gastric emptying after LSG [5]. The fact that the fundus of the stomach, the main location of ghrelin-producing cells, is removed during LSG (confirmed by either a decrease of ghrelin levels or no change in the LGS group compared to RYGB $[6,7])$ led to speculation that ghrelin could play a role in the mechanism of action. Moreover, the suppression of ghrelin levels after LSG was associated with greater appetite reduction and increased weight loss during the first post-operative year compared to RYGB [8].

There is limited information regarding the relationship between ghrelin and antioxidant enzymes after LSG and their direct role in diabetes remission. It is especially important to understand whether the beneficial metabolic effects of bariatric surgery are solely related to weight loss, changes in gut physiology and secretion of gut hormones and/or improved adipose-tissue inflammation and oxidantantioxidant status.

The value of the well-known oxidative stress biomarkers for the assessment of physiological changes induced by LSG has been (so far) only scarcely analysed in diabetic patients. There are few published studies examining changes in antioxidant enzymes after LSG compared with other bariatric surgery techniques [9-12]. Thus, in a combined cohort of RYGB and LSG patients, significant improvements in markers of both oxidative stress and inflammation have been reported [12] and these were not linked to ghrelin levels after interventions. The aim of the current study was to examine the impact of LSG versus conservatory treatment (dietary treatment group - DTG) on oxidant-antioxidant profile in obese T2D male patients. Of special interest, we present a comprehensive investigation of the antioxidant profile at baseline and after 6 months of follow-up (LSG vs. DTG). We also focused on of plasma 8-OH-2-deoxiguanosine levels - a good biomarker for the oxidative modification of DNA under oxidative stress conditions [13-14] and furthermore a marker of the metabolic oxidative status of obese T2D patients [15].

Finally, we assessed the relationship between ghrelin and antioxidant enzymes (both easy to measure in blood samples) both possible markers for predicting T2D remission.

\section{Materials and Methods}

Patients

The study was a randomized controlled study for which obese participants (body mass index, BMI $\geq 30$ $\mathrm{kg} / \mathrm{m}^{2}$ ), all men, were randomly selected from a group of 80 Caucasian patients aged 30 - 65 years. All subjects were in good general condition. The study was approved by the local Ethics Committee from "Ponderas" Hospital and "Prof. N. C. Paulescu" National Institute of Diabetes, Nutrition and Metabolic Disease, Bucharest. Written informed consent was obtained from all studied subjects prior to screening. Subjects fulfilling the inclusion criteria (T2D, obesity, age 30 - 65 years, diabetes duration 1 - 15 years, acceptance and financial capability to cover the costs of nutritional supplements after LSG) were included in the study. Exclusion criteria were type 1 diabetes, C-peptide $<0.81 \mathrm{ng} / \mathrm{mL}, \mathrm{HbA}_{1 \mathrm{c}}<$ $6.5 \%$, anaemia with $\mathrm{Hb}<10 \mathrm{~g} / \mathrm{dL}$, the presence of active liver disease or hepatic dysfunction (hepatitis $\mathrm{B}$ or $\mathrm{C}$, cirrhosis), renal disease (serum creatinine $>$ $1.2 \mathrm{mg} / \mathrm{dL}$ or GFR $<60 \mathrm{~mL} / \mathrm{min} / 1.73 \mathrm{~m}^{2}$ ), malignancies, coronary artery disease with myocardial infarction or stroke in the last 12 months, smoking, alcoholism, drug dependence. No participant had any diagnosed systemic immune disorders and was known to be taking any form of vitamin supplementation neither at the time of recruitment nor after inclusion in this study.

Detailed information regarding the procedures of this study was previously reported [16]. Briefly, 17 patients from the DTG and 19 from the LSG were evaluated after 6 months of follow up. All subjects consulted a nutritionist before and during the study for dietary advice and instructions on preparation of their diets to assure good adherence to the study. Detailed presentation of the diet intervention was previously described [16]. In brief, individualized calorie count was based on the estimated Resting Metabolic Rate (RMR) from which a $500 \mathrm{kcal}$ daily restriction was subtracted.

Blood sampling and analysis

At the time of screening, the following clinical information was collected: age, medical history, weight, height, treatment and duration of type 2 diabetes, systolic and diastolic blood pressure. The body mass index (BMI $\mathrm{kg} / \mathrm{m}^{2}$ ) was calculated. Baseline biochemical measurements, $\mathrm{HbA}_{1 \mathrm{c}}$ (by PLC method on D10-Bio Rad Analyser), blood count (by automatic photometric method on Cell-Dyn 3700 BioRad Analyser), rapid serological tests for HIV, hepatitis $\mathrm{B}$ and $\mathrm{C}$ were performed by the Research Laboratory of the "Prof. N. C. Paulescu" National Institute of Diabetes, Nutrition and Metabolic 
Diseases, Bucharest. C-peptide was also measured by ELISA method (kit EIA-1293; CV 6.12\%; DRG Instruments, Germany), following the manufacturer's guidelines. Participants that did not have complete data for these tests were not involved in the randomization process.

For all randomized subjects we collected blood samples into vacuum tubes without anticoagulant (for biochemistry tests and ELISA assays), vacuum tubes with EDTA (for oxidative stress parameters) or with aprotinin (for ghrelin assay). All samples were collected after 12 hours fasting, centrifuged and separated within 1 hour of collection. Samples were subsequently either processed or stored at $-80^{\circ} \mathrm{C}$ until analysis. Biochemical measurements included: fasting blood glucose (FBG), total cholesterol, high-density lipoprotein (HDL) cholesterol, triglycerides, uric acid, urea, creatinine, AST (aspartate amino-transferase), ALT (alanine aminotransferase), GGT ( $\gamma$-glutamyl-transferase) and were performed with standard kits according to the manufacturer instructions on an Eos Bravos Forte Hospitex Diagnostics bio-chemistry analyser. LDLcholesterol was calculated according to the Friedewald formula [17]. HOMA-IR (Homeostasis Model Asessment for Insulin Resistance) was calculated as [glycaemia $(\mathrm{mmol} / \mathrm{L}) \mathrm{x}$ insulinemia $(\mu \mathrm{U} / \mathrm{mL})$ ]: 22.5 [18]. Hormones including insulin, Cpeptide, ghrelin, leptin and adiponectin were determined by ELISA method on an automatic microplate reader Multiskan Ex-Thermo Electro Corporation using commercially available kits (EIA-2935, EIA-1293, EIA-4710, EIA-2395 and EIA-4177; DRG Instruments, Germany) and following the manufacturer's guide-lines. Fasting EDTA samples were collected for the measurement of oxidative stress markers, as described below. All samples were analysed in the same laboratory both at baseline and 6 months.

\section{Isolation of PBMNC and Respiratory Burst}

Peripheral blood mononuclear cells (PBMNC) were isolated by density centrifugation on FicollPaque $^{\mathrm{TM}}$ Plus $(1.0077 \mathrm{~g} / \mathrm{mL})$ after centrifugation at $600 \mathrm{~g}$ for 30 minutes and, washed twice. Subsequently cells were re-suspended in $1 \mathrm{~mL}$ PBS (Dulbecco's Phosphate Buffered Saline) and used directly for the experiments. Cell viability evaluated by Trypan Blue exclusion was always $\geq 90 \%$. The capacity to have a Respiratory Burst (RB) was monitored by lucigenin or luminol-enhanced chemiluminescence (Luminoskan Ascent ${ }^{\circledR}$ 392, Labsystems) at $37^{\circ} \mathrm{C}$ [19]. Briefly, PBMNC resuspended in PBS with calcium and magnesium were plated in a 96-well plate and dark-adapted luminol or lucigenin (final concentration 143 $\mu \mathrm{mol} / \mathrm{L}$ ) was added. After monitoring spontaneous chemi-luminescence for $10 \mathrm{~min}$, the $\mathrm{RB}$ was initiated by adding of phorbol 12-myristate 13- acetate (PMA; final concentration $5.4 \mu \mathrm{mol} / \mathrm{L}$ ) or Opsonised Zymosan (OZ, final concentration 0.83 $\mathrm{g} / \mathrm{L})$. Chemiluminescence measurements were performed in duplicate every $30 \mathrm{~s}$ over a 60 -minutes period for PBMNC. Free radical production was expressed as the mean \pm SEM of the maximal emission of relative chemiluminescence units over time (RLU x $60 \mathrm{~min}$ ) and the peak value (maximum RLU) reached.

Evaluation of oxidant and antioxidant redox state Determination of the serum 8-OH-2deoxiguanosine $(8-\mathrm{OH}-2 \mathrm{dG})$ concentrations was performed with a competitive ELISA kit (Abcam) using a monoclonal antibody specific for $8-\mathrm{OH}-$ $2 \mathrm{dG}$ and an acetylcholin-esterase (AChE) conjugated 8-OH-2-dG tracer according to the manufacturer instructions; the substrate for AChE is contained in the developing reagent, and the yellow enzymatic reaction product was determined spectrophotometrically at $412 \mathrm{~nm}$.

Antioxidant enzymes PON1, arylesterase (PON1phe) and lactonase 1 (PON1dhe) activities were measured toward $1 \mathrm{mM}$ phenylacetate in 20 $\mathrm{mM}$ Tris $/ \mathrm{HCl} \quad \mathrm{pH} \quad 8.0$ or $1 \mathrm{mmol} / \mathrm{L} \quad \mathrm{DHC}$ respectively. The reaction was started by the addition of the serum and the increase in absorbance was read at $270 \mathrm{~nm}$ using a UV-VIS spectrophotometer. Blanks were included to correct the spontaneous hydrolysis of substrate. One unit (U) of arylesterase (PON1phe) is defined as $1 \mathrm{pmol}$ of p-nitrophenol hydrolysed per minute using the extinction coefficient of $1310 \mathrm{M}^{-1} \mathrm{~cm}^{-1}$ while one unit of lactonase activity (PON1dhe) is equal to 1 $\mu \mathrm{mol}$ of DHC hydrolysed $/ \mathrm{mL} / \mathrm{min}$ using the extinction coefficient of $1295 \mathrm{M}^{-1} \mathrm{~cm}^{-1}$ [20]. The intra- and inter-assay coefficients of variation were $<5 \%$ in all tests.

Superoxide Dismutase (SOD) and Glutation Peroxidase (GPx) were measured by using kit no. K9120 for SOD and kit no. 30-7031 for GPx, respectively (Sigma-Aldrich Co. LLC., St Louis, USA), after extraction with chlorophorm/ethanol and according to the producer recommendations. Results are expressed as $\mathrm{U} / \mathrm{g} \mathrm{Hb}$.

The method of determining the activity of erythrocyte catalase (CAT) is based on the decrease in the absorbance of $\mathrm{H}_{2} \mathrm{O}_{2}$ at $240 \mathrm{~nm}$ with decreasing concentration. The initial haemolysate obtained was diluted with $50 \mathrm{mM}$ phosphate buffer ( $\mathrm{pH}$ 7.0), and the reaction was initiated with $\mathrm{H}_{2} \mathrm{O}_{2}$. The results were expressed in $\mathrm{k} / \mathrm{g} \mathrm{Hb}$.

Determination of erythrocytes non-proteic glutathione (GSH) was performed on total blood samples (200 $\mu \mathrm{L})$ after precipitation with metaphosphoric acid solution, $\mathrm{Na}_{2}$ EDTA and $\mathrm{NaCl}$. After centrifugation at $4000 \mathrm{rpm}, 15$ minutes at $4^{\circ} \mathrm{C}$, over $250 \mu \mathrm{L}$ of the supernatant was added $1 \mathrm{~mL}$ of $0.3 \mathrm{M}$ phosphate buffer and $125 \mu \mathrm{L}$ of DTNB (Ellman reagent: 5,5'- 
dithiobis-2-nitrobenzoic acid) and absorbance was read at $405 \mathrm{~nm}$. The results were expressed as $\mu \mathrm{g} / \mathrm{g}$ $\mathrm{Hb}$.

Reagents used: Dulbecco's Phosphate Buffered Saline (PBS) with or without calcium and magnesium, was from Invitrogen, Paisley, UK. Phorbol 12myristate 13-acetate (PMA), luminol (5-amino-2,3dihydro-1,4-phthalazinedione; LM), lucigenin (N,N'-dimethyl-9,9'-biacridinium dinitrate; LG), zymosan A from Saccharomyces cerevisiae (ZO), and dihydrocoumarin (DHC) were purchased from Sigma Chemical Co., St. Louis, MO, USA.

Statistical analysis

Testing normality of distribution was performed using the Kolmogorov-Smirnov test. The results for continuous variables with normal distribution are presented as mean \pm standard deviation (SD). Some variables that had no normal distribution were logarithmic transformed to normalize their distribution and subsequently analysed. Results for variables that do not follow a normal distribution are presented as median and interquartile range (25 $75)$. Results for categorical variables are presented as percentages. For the comparison of two independent groups of variables with normal distribution we used the Student $t$ test for independent samples. To highlight the degree of association between two categorical variables we used the chisquare test (Chi-Square) while the Mann-Whitney U Test was used for ordinal or quantitative variables that do not follow a normal distribution. Testing the difference between more than two groups was done by applying simple Anova (One-Way Anova) for normally distributed variables and applying quantitative Kruskal-Wallis test for quantitative variables without normal distribution or ordinal variables. Pearson bivariate correlation method was used to examine correlations between variables. In some tests we used logistic regression to assess the contribution of different independent variables to predict the presence of dependent variables. Statistical significance was defined at $\mathrm{p}<0.05$.

\section{Results and Discussion}

The baseline characteristics of the two study groups are shown in Table I. At 6 months, the target glycated haemoglobin level of $6.0 \%$ or less was achieved in $89 \%$ of the patients in the LSG, as compared with $14 \%$ of those in the DTG (p < 0.0001). In the entire cohort, a reduction in the BMI was the only significant predictor of achieving the primary end point of $\mathrm{HbA}_{1 \mathrm{c}}<6 \%$ (odds ratio for each 1-unit decrease in BMI, 1.41; $95 \%$ confidence interval $[\mathrm{CI}], 1.22$ to $1.64 ; \mathrm{p}<0.001)$. The following parameters had to be transformed logarithmically to approximate normal distributions: blood glucose, HbA1C, insulin, HOMA-IR, triglyceride, total and LDL-C, and adiponectin. We also analysed the effect of LSG vs DTG on the levels of appetite-controlling hormones such as ghrelin levels. Thus, we found a statistically significant decrease of ghrelin and GLP-1 levels in LSG but not in DTG (Figures 1A and 1B).

Regarding the oxidative stress profile, laparoscopic gastric sleeve intervention was previously shown to induce a significant decrease in subclinical inflammation in parallel with weight loss [21, 22], and was associated with increased levels of the DNA damage products [23] as also expressed in our study by CRP and 8 -oxo- $2 \mathrm{dG}$ values. The decrease is significant at 6 months for both groups at the level $\mathrm{p}<0.05$ for the DTG and $<0.001$ for the LSG group.

Table I

The clinical and biochemical characteristics of diabetic subjects in the two study groups at baseline and 6 months

\begin{tabular}{|c|c|c|c|c|c|c|}
\hline & \multicolumn{2}{|c|}{ DTG } & \multicolumn{4}{|c|}{ LSG } \\
\hline & $\begin{array}{c}\text { Baseline } \\
(\mathrm{n}=17)\end{array}$ & $\begin{array}{c}6 \text { months } \\
(n=17)\end{array}$ & p-value & $\begin{array}{r}\text { Baseline } \\
(\mathrm{n}=19)\end{array}$ & $\begin{array}{c}6 \text { months }(n= \\
19)\end{array}$ & p-value \\
\hline Waist Circumference (cm)* & $139.00(14.0)$ & $133.00(10.00)$ & $<0.05^{1}$ & $134.00(16.0)$ & $105.00(10.5)$ & $<0.001^{1}$ \\
\hline Body Mass Index $\left(\mathrm{kg} / \mathrm{m}^{2}\right)^{*}$ & $40.50(8.60)$ & $39.10(8.30)$ & $<0.001^{1}$ & $39.60(4.90)$ & $29.30(2.25)$ & $<0.001^{1}$ \\
\hline SBP (mmHg)* & $135.00(12.0)$ & $120.00(10.00)$ & $<0.05^{1}$ & $130.00(13.75)$ & $125.00(30.50)$ & $n s^{1}$ \\
\hline DBP (mmHg)* & $90.00(10.00)$ & $80.00(20.00)$ & $\mathrm{ns}^{1}$ & $80.00(10.00)$ & $82.00(13.00)$ & $<0.05^{1}$ \\
\hline $\mathrm{HbA}_{1 \mathrm{c}}(\%)^{*}$ & $7.56(1.87)$ & $7.91(2.62)$ & $\mathrm{ns}^{1}$ & $8.40(1.45)$ & $6.60(0.75)$ & $<0.001^{1}$ \\
\hline Glycemia $(\mathrm{mg} / \mathrm{dL}) *$ & $184.50(99.3)$ & $145.17(103.63)$ & $\mathrm{ns}^{1}$ & $197.70(107.4)$ & $99.56(27.48)$ & $<0.001^{1}$ \\
\hline Serum total cholesterol $(\mathrm{mg} / \mathrm{dL})^{\#}$ & $194.14 \pm 26.75$ & $191.16 \pm 55.01$ & $\mathrm{~ns}^{2}$ & $184.65 \pm 36.04$ & $184.55 \pm 32.05$ & $\mathrm{~ns}^{2}$ \\
\hline HDLc (mg/dL)* & $36.10(8.20)$ & $35.30(9.50)$ & $\mathrm{ns}^{1}$ & $34.20(8.15)$ & $39.20(9.90)$ & $0.05^{1}$ \\
\hline Trigliceride (mg/dL)* & $187.40(123.26)$ & 167.35 & $n s^{1}$ & $178.23(137.50)$ & $89.43(48.30)$ & $<0.001^{1}$ \\
\hline $\operatorname{LDLc}(\mathrm{mg} / \mathrm{dL})^{*}$ & $121.15(31.6)$ & $119.86(42.86)$ & $\mathrm{ns}^{1}$ & $111.15(34.7)$ & $126.54(17.5)$ & $\mathrm{ns}^{1}$ \\
\hline Uric acid $(\mathrm{mg} / \mathrm{dL})^{*}$ & $5.99(1.45)$ & $6.38(1.54)$ & $\mathrm{ns}^{1}$ & $5.89(2.34)$ & $6.51(2.19)$ & $\mathrm{ns}^{1}$ \\
\hline $\mathrm{C}$ reactive Protein $(\mathrm{mg} / \mathrm{L})^{*}$ & $6.34(6.21)$ & $9.13(7.34)$ & $<0.05^{1}$ & $9.47(4.85)$ & $3.43(8.95)$ & $<0.05^{1}$ \\
\hline HOMA-IR (CP)* & $8.12(14.02)$ & $7.35(5.70)$ & $\mathrm{ns}^{1}$ & $8.44(10.56)$ & $1.68(1.70)$ & $<0.001^{1}$ \\
\hline
\end{tabular}

SBP systolic blood presure; DBP diastolic blood presure, HOMA-IR Homeostasis Model Asessment for Insulin Resistance; * - Median and $\mathrm{IQR}$ range; ${ }^{\#}$ - mean $\pm \mathrm{SD} ;{ }^{1}$ - Wilcoxon signed rank test; ${ }^{2}$ - Paired $\mathrm{T}$ Test; ns $=$ not significant 
The levels and ratios of hormones measurements are shown in Table II, at baseline and 6 months follow-up. We found a significant decrease of insulin $(\mathrm{p}<0.001)$, proinsulin $(\mathrm{p}<0.001)$, C peptide $(\mathrm{p}<$ $0.05)$ and leptin $(\mathrm{p}<0.001)$ while adiponectin had a significant increase following LSG $(\mathrm{p}<0.001)$.
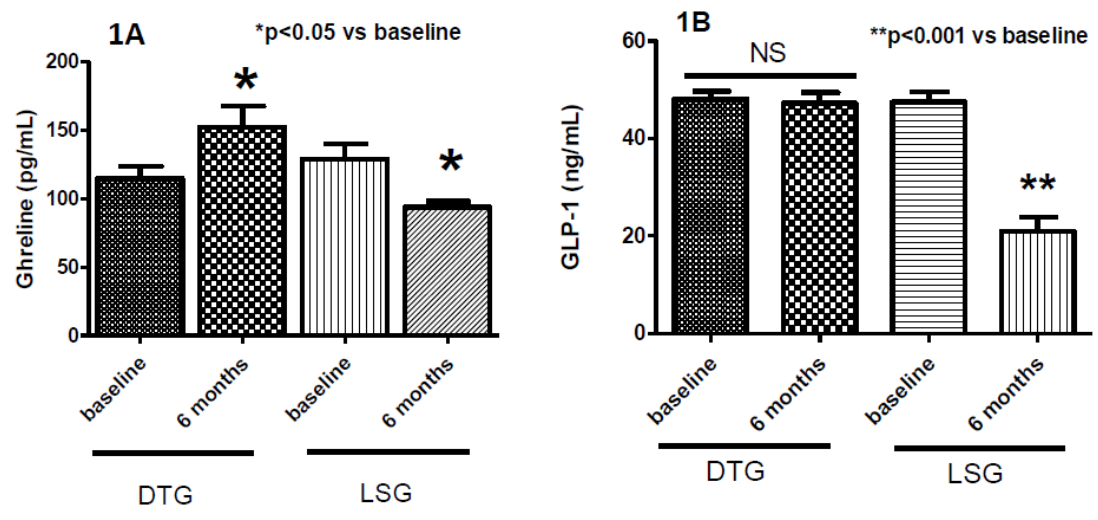

Figure 1.

V Ghrelin (1A) and GLP-1 (1B) levels in diet (DTG) and sleeve gastrectomy patients (LSG) at baseline and 6 months follow-up

Table II

Levels and ratios of hormones in diabetic patients at baseline and 6 months follow-up

\begin{tabular}{|c|c|c|c|c|c|c|}
\hline & \multicolumn{2}{|c|}{ DTG } & \multicolumn{4}{|c|}{ LSG } \\
\hline & Baseline $(n=21)$ & 6 months $(n=17)$ & p-value & Baseline $(n=20)$ & 6 months $(n=19)$ & p-value \\
\hline Insulin $(\mu \mathrm{UI} / \mathbf{m L})^{*}$ & $22.12(23.41)$ & $17.43(12.71)$ & $\mathrm{ns}^{1}$ & $18.92(24.35)$ & $6.67(5.68)$ & $<0.001^{1}$ \\
\hline C Peptide (ng/mL)* & $9.82(2.53)$ & $7.66(2.10)$ & $\mathrm{ns}^{1}$ & $9.72(1.33)$ & $7.39(2.09)$ & $<0.05^{1}$ \\
\hline Leptin $(\mathrm{ng} / \mathrm{mL}) *$ & $15.50(7.66)$ & $10.16(12.78)$ & $<0.05^{1}$ & $8.45(6.39)$ & $2.62(1.29)$ & $<0.001^{1}$ \\
\hline Adiponectin $(\mu \mathrm{g} / \mathrm{mL}) *$ & $4.82(9.28)$ & $3.98(6.50)$ & $\mathrm{ns}^{1}$ & $2.09(1.09)$ & $3.63(5.58)$ & $<0.001^{1}$ \\
\hline
\end{tabular}

Table III

Oxidative stress markers in diabetic patients at baseline and 6 months follow-up

\begin{tabular}{lccccc}
\hline \multirow{2}{*}{ Parameters } & \multicolumn{2}{c}{ Baseline } & \multicolumn{2}{c}{ 6 months } & \\
& DTG & LSG & DTG & LSG & p-value \\
& $(\mathbf{n = 2 1 )}$ & $(\mathbf{n = 2 0})$ & $(\mathbf{n}=\mathbf{1 7})$ & $(\mathbf{n}=\mathbf{1 9})$ & \\
\hline RB LM/PMA (Maximum RLU) & $0.06 \pm 0.01$ & $0.19 \pm 0.05$ & $0.09 \pm 0.02$ & $0.17 \pm 0.04$ & $\mathrm{~ns}$ \\
RB LG/PMA (Maximum RLU) & $0.01 \pm 0.00$ & $0.01 \pm 0.00$ & $0.01 \pm 0.00$ & $0.01 \pm 0.00$ & $\mathrm{~ns}$ \\
RB LM/OZ (Maximum RLU) & $0.12 \pm 0.03$ & $0.33 \pm 0.09$ & $0.23 \pm 0.06^{*}$ & $0.37 \pm 0.00$ & $<0.05$ \\
RB LG/OZ (Maximum RLU) & $0.01 \pm 0.00$ & $0.02 \pm 0.00$ & $0.02 \pm 0.00$ & $0.02 \pm 0.00$ & $\mathrm{~ns}$ \\
GSH ( $\mu$ g/g Hb) & $0.27 \pm 0.01$ & $0.26 \pm 0.01$ & $0.28 \pm 0.01$ & $0.23 \pm 0.00^{* *}$ & $<0.05$ \\
plasma 8-OH-2dG & $10.31 \pm 0.54$ & $13.10 \pm 2.14$ & $10.15 \pm 1.82$ & $12.04 \pm 0.70$ & $\mathrm{~ns}$ \\
\hline
\end{tabular}

RB, respiratory burst; PMA, phorbol 12-myristate 13-acetate; ZO, opsonized zymosan; LM, luminol; LG, lucigenin; Maximum, the maximal peak value; RLU, Relative Chemiluminescence Units; 8-OH-2dG, 8-hydroxy-2-deoxyguanosine. Data are expressed as mean \pm SEM (standard error of the mean). The p-value refers to the comparison between DTG and LSG after 6 months; ${ }^{*}$ and ${ }^{* *}$ denote $\mathrm{p}<0.05$ and $\mathrm{p}<0.001$ when comparing 6months to baseline within each group; ns = not significant

The results of oxidative stress markers for the two study groups are shown in Table III. At 6 months post-surgery, activities of SOD and PON1 (PON1phe and PON1dhc) were not different in the LSG group when compared with DTG group (Figures 2A, 2D and 2E). There was a significant increase in GPx and CAT activities in both studied groups at 6 months compared to baseline (Figures $2 \mathrm{~B}$ and $2 \mathrm{C}$ ).
Correlations of hormonal and oxidative stress markers with diabetes remission/metabolic control To determine the impact of hormonal and oxidative stress markers on the improvement of metabolic control we used a univariate conditional regression model with the outcome of not reaching T2D remission $\left(\mathrm{HbA}_{1 \mathrm{c}}>6 \%\right)$ after $\mathrm{LSG}$ and as predictors the parameters studied. 

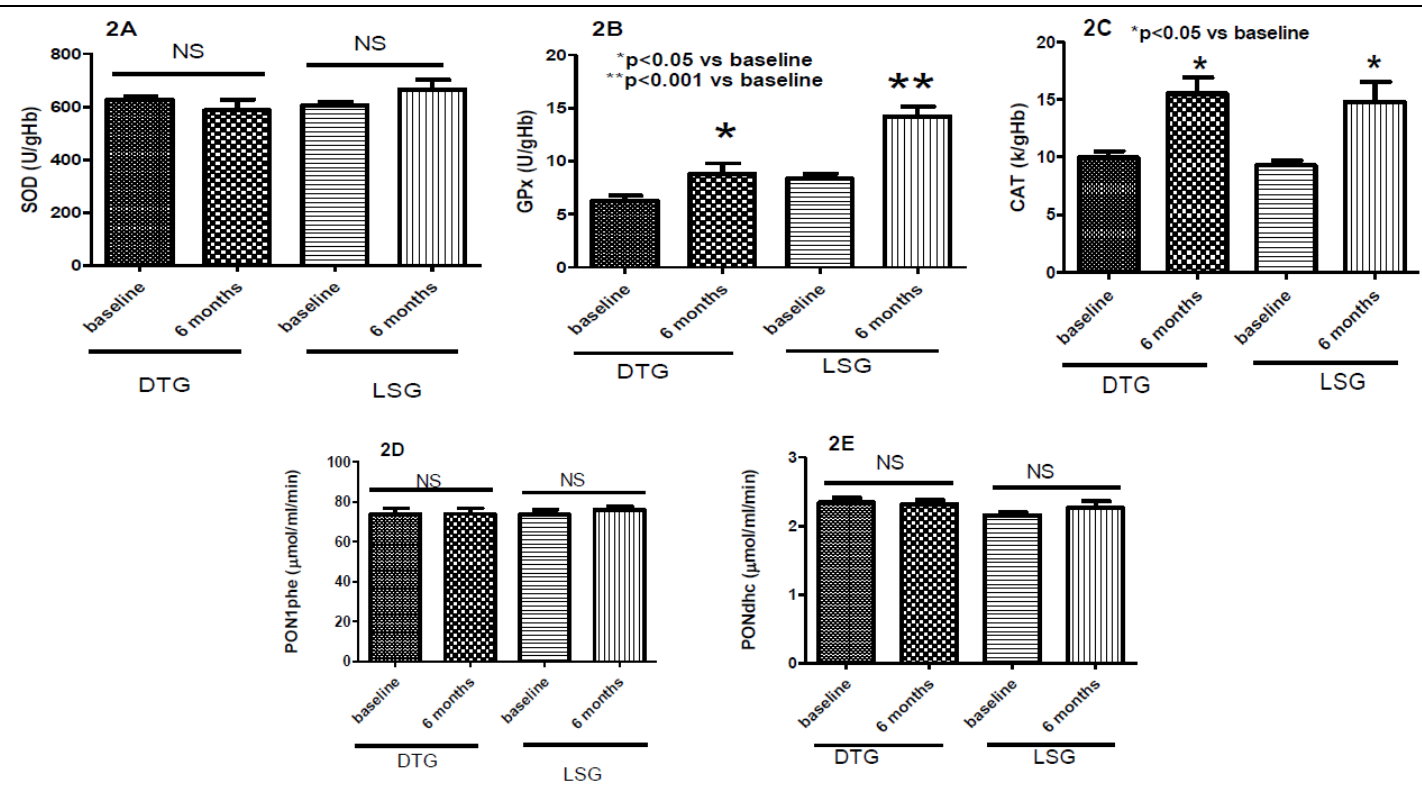

Figure 2.

Antioxidant enzymes in diet (DTG) and sleeve gastrectomy (LSG) patients at baseline and 6 months follow-up (2A) Superoxide dismutase (SOD); (2B) Glutation peroxidase (GPx); (2C) Catalase; (2D) Paraoxonase 1 phenylacetate activity (PON1phe); (2E) Paraoxonase 1 lactonase activity (PON1dhc)

The levels of adiponectin were correlated negatively with the waist circumference $(r=-0.49$, $\mathrm{p}<0.001)$, diastolic BP $(\mathrm{r}=-0.30, \mathrm{p}<0.05)$, levels of uric acid $(\mathrm{r}=-0.33, \mathrm{p}<0.001)$, glucose $(\mathrm{r}=$ $0.30, \mathrm{p}<0.05)$. There were no statistically significant correlations between ghrelin and none of the studied parameters.

Six months after LSG, the results of this follow-up analysis show that, LGS, as compared with diet group treated alone, LSG was associated with superior and sustained glycaemic control and weight reduction (Table I). At 6 months postsurgery, the mean BMI has dropped to 37.1 (range 28.4 - 40.6). Patients who underwent sleeve gastrectomy were significantly more likely to achieve and maintain a glycated haemoglobin level of $6.0 \%$ than were those who received intensive medical therapy alone. Patients in the LSG had a significant decrease of almost $82 \%$ of the percentage of excess loss, as compared with a reduction of about $10 \%$ in the DTG group. More than $90 \%$ of surgical patients who had a shorter duration of diabetes achieved an $\mathrm{HbA}_{1 \mathrm{c}}<6 \%$, diabetes duration being the main predictors of having a glycated haemoglobin level of $6.0 \%$ or less post-surgery. Analysis of 6 months follow-up for oxidative stress markers, including $\mathrm{RB}, 8-\mathrm{OH}-2 \mathrm{dG}$, and levels of antioxidant enzymes, also showed favourable results in the surgical groups, as compared with the group receiving intensive medical therapy alone.

Of the parameters investigated, PON1dhe activity correlated positively with concentrations of HDL-C and adiponectin $(\mathrm{p}<0.05)$, and correlated negatively with BMI, waist circumference, SBP, levels of $\mathrm{HbA}_{1 \mathrm{C}}$, insulin and HOMA-IR ( $\left.\mathrm{p}<0.05\right)$. The positive correlation between adiponectin and PON1 dhe remained significant even after adjustments for age, gender, BMI, blood pressure, HOMA-IR, HDL-C and LDL-C. There were no statistically significant correlations between ghrelin and all of the studied parameters.

By using univariate conditional regression model we were able to highlight that patients with an unfavourable evolution for T2D remission $\left(\mathrm{HbA}_{1 \mathrm{c}}>\right.$ $6 \%$ ) had higher values (at baseline and after 6 months) for BMI, WC, C peptide, CRP and lower values (at baseline and 6 months) for HDL and adiponectin (as an anti-inflammatory factor).

\section{Conclusions}

In conclusion, our results suggests that significant weight fluctuations can directly influence antioxidant enzyme profiles and may play an important role in the mediation of weight loss and the beneficial metabolic effects of LSG.

\section{Acknowledgement}

This work was funded through the Programme "Partnership in priority areas" by the MEN-UEFISCDI, project number PN-II-PT-PCCA-2013-4-2154. We are grateful to acknowledge Manuela Mitu and Janeta Tudosoiu from the research laboratory of NIDNMB "Prof. N. Paulescu", for excellent technical assistance and to Dr. Constantin Popescu Dan for statistical analysis of the data. 


\section{Conflict of interest}

The authors have declared that there is no conflict of interest.

\section{References}

1. Hagopian K, Harper ME, Ram JJ, Humble SJ, Weindruch R, Ramsey JJ, Longterm calorie restriction reduces proton leak and hydrogen peroxide production in liver mitochondria. $\mathrm{Am} \mathrm{J}$ Physiol Endocrinol Metab., 2005; 288: E674-E84.

2. Buchwald HY, Avidor E, Braunwald E, Jensen MD, Pories W, Fahrbach K, Schoelles K, Bariatric surgery: a systematic review and meta-analysis. $J$ Am Med Assoc., 2004, 292(14): 1724-1737.

3. Dimitrios J, Pournaras, Carel W, Roux LE, Ghrelin and metabolic surgery. Int $J$ Peptides, 2010; 2010: $1-5$.

4. Bernstine H, Tzioni-Yehoshua R, Groshar D, Gastric emptying is not affected by sleeve gastrectomyscintigraphic evaluation of gastric emptying after sleeve gastrectomy without removal of the gastric antrum. Obes Surg., 2009; 19(3): 293-298.

5. Vidal J, Ibarzabal A, Romero F, Delgado S, Momblán D, Flores L, Lacy A, Type 2 diabetes mellitus and the metabolic syndrome following sleeve gastrectomy in severely obese subjects. Obes Surg., 2008; 18: 1077-1082.

6. Langer FB, Hoda MAR, Bohdjalian A, Sleeve gastrectomy and gastric banding: effects on plasma ghrelin levels. Obes Surg., 2005; 15(7): 1024-1029.

7. Wang Y, Liu J, Plasma ghrelin modulation in gastric band operation and sleeve gastrectomy. Obes Surg., 2009; 19(3): 357-362.

8. Karamanakos SN, Vagenas K, Kalfarentzos F, Alexandrides TK, Weight loss, appetite suppression, and changes in fasting and postprandial ghrelin and peptide-YY levels after Roux en-Y gastric bypass and sleeve gastrectomy: a prospective, double blind study. Annals of Surgery, 2008; 247(3): 401-407.

9. Lakdawala MA, Bhasker A, Mulchandani D, Goel S, Jain S, Comparison between the results of laparoscopic sleeve gastrectomy and laparoscopic Roux-en-Y gastric bypass in the Indian population: a retrospective 1 year study. Obes Surg., 2010; 20(1): $1-6$.

10. Kelly AS, Ryder JT, Marlatt KL, Rudser KD, Jenkins $\mathrm{T}$, Inge $\mathrm{TH}$, Changes in inflammation, oxidative stress and adipokines following bariatric surgery among adolescents with severe obesity. Int $J$ Obes., 2016; 40: 275-280.

11. Lager CJ, Esfandiari NH, Subauste AR, Kraftson AT, Brown MB, Cassidy RB, Nay KC, Lockwood AL, Varban OA, Oral EA, Roux-En-Y gastric bypass vs. sleeve gastrectomy: Balancing the risks of surgery with the benefits of weight loss. Obes Surg., 2017; 27: 154-161.

12. Kelly AS, Ryder JR, Marlatt KL, Rudser KD, Jenkins $\mathrm{T}$, Inge $\mathrm{TH}$, Changes in inflammation, oxidative stress and adipokines following bariatric surgery among adolescents with severe obesity. Int $J$ Obes., 2016; 40: 275-280.

13. Voulgaridou GP, Anestopoulos I, Franco R, Panayiotidis MI, Pappa A, DNA damage induced by endogenous aldehydes: current state of knowledge. Mutat Res., 2011; 711(1-2): 13-27.

14. Shibutani S, Takeshita M, Grollman AP, Insertion of specific bases during DNA synthesis past the oxidation-damaged base 8-oxo-dG. Nature, 1991; 349: 431-434.

15. Shin CS, Moon BS, Park KS, Seong YK, Su JP, Chung MH, Lee HK, Serum 8-hydroxy-guanine levels are increased in diabetic patients. Diabetes Care, 2001; 24: 733-737.

16. Ştefan DS, Mihai A, Bajko D, Lixandru D, Petcu L, Picu A, Smeu B, Copăescu C, Ionescu-Tîrgovişte C, Guja C, Comparison of sleeve gastrectomy and conservatory treatment effect on biochemical and hormonal profile of obese type 2 diabetes subjects: CREDOR randomized controlled study results. Rev Chem (Bucharest), 2017; 68: 1622-1627.

17. Friedewald WT, Levy RT, Fredrickson DS, Estimation of the concentration of low-density lipoprotein cholesterol in plasma, without use of the preparative ultracentrifuge. Clin Chem., 1972; 18: 499-502.

18. Matthews DR, Hosker JP, Rudenski AS, Naylor BA, Treacher DF, Homeostasis model assessment: insulin resistance and beta-cell function from fasting plasma glucose and insulin concentrations in man. Diabetologia, 1985; 28: 412-419.

19. Allen RC, Loose LD, Phagocytic activation of a luminol-dependent chemiluminescence in rabbit alveolar and peritoneal macrophages. Biochem Biophysic Res Communications, 1976; 69: 245-252.

20. Draganov DI, Stetson PL, Watson CE, Billecke SS, $\mathrm{La} \mathrm{Du} \mathrm{BN}$, Rabbit serum paraoxonase 3 (PON3) is a high density lipoprotein-associated lactonase and protects low density lipoprotein against oxidation. $J$ Biol Chem., 2000; 275: 33435-33442.

21. Morshed G, Samah M, Fathy Impact of postlaparoscopic sleeve gastrectomy weight loss on Creactive protein, lipid profile and $\mathrm{CA}-125$ in morbidly obese women. Videosurgery Miniinv, 2015; 10 (4): 521-526.

22. Buchwald H, Estok R, Fahrbach K, Banel D, Jensen MD, Pories WS, Bantle JP, Sledge I, Weight and Type 2 Diabetes after Bariatric Surgery: Systematic Review and Meta-analysis. $\mathrm{Am}$ J Med, 2009; 122: 248-256.

23. Banks KA, Murphy KG, Role of ghrelin in glucose homeostasis and diabetes. Diabetes Manage., 2013; 3(2): 171-182. 